\title{
Herbaspirillum lusitanum sp. nov., a novel nitrogen-fixing bacterium associated with root nodules of Phaseolus vulgaris
}

\author{
Angel Valverde, ${ }^{1}$ Encarna Velázquez, ${ }^{2}$ Carmen Gutiérrez, ${ }^{3}$ \\ Emilio Cervantes, ${ }^{1}$ Antonio Ventosa ${ }^{3}$ and José-Mariano Igual ${ }^{1}$ \\ 'Departamento de Producción Vegetal, Instituto de Recursos Naturales y Agrobiología, Consejo \\ Superior de Investigaciones Científicas, Apartado 257, 37071 Salamanca, Spain \\ ${ }^{2}$ Departamento de Microbiología y Genética, Universidad de Salamanca, 37007 Salamanca, \\ Spain \\ ${ }^{3}$ Departamento de Microbiología y Parasitología, Facultad de Farmacia, Universidad de Sevilla, \\ 41012 Sevilla, Spain
}

Correspondence José-Mariano Igual igual@usal.es

\begin{abstract}
Several bacterial strains were isolated from root nodules of Phaseolus vulgaris plants grown in a soil from Portugal. The strains were Gram-negative, aerobic, curved rod-shaped and motile. The isolates were catalase- and oxidase-positive. The TP-RAPD (two-primer randomly amplified polymorphic DNA) patterns of all strains were identical, suggesting that they belong to the same species. The complete $16 \mathrm{~S}$ rDNA sequence of a representative strain was obtained and phylogenetic analysis based on the neighbour-joining method indicated that this bacterium belongs to the $\beta$-Proteobacteria and that the closest related genus is Herbaspirillum. The DNA G $+\mathrm{C}$ content ranged from 57.9 to $61.9 \mathrm{~mol} \%$. Growth was observed with many different carbohydrates and organic acids including caprate, malate, citrate and phenylacetate. No growth was observed with maltose, meso-inositol, meso-erythritol or adipate as sole carbon source. According to the phenotypic and genotypic data obtained in this work, the bacterium represents a novel species of the genus Herbaspirillum, and the name Herbaspirillum lusitanum sp. nov. is proposed. The type strain is P6-12 ${ }^{\top}$ (= LMG $21710^{\top}=$ CECT $5661^{\top}$ ).
\end{abstract}

The genus Herbaspirillum was first described with a single species, Herbaspirillum seropedicae, that included bacterial strains associated with roots of several cereals (Baldani et al., 1986). Three other species have since been included: Herbaspirillum rubrisubalbicans (Baldani et al., 1996), a mild pathogen of sugarcane formerly named Pseudomonas rubrisubalbicans, Herbaspirillum species 3 (Baldani et al., 1996; Gillis et al., 1990), which contains mainly strains of clinical origin, and, more recently, Herbaspirillum frisingense (Kirchhof et al., 2001), which occurs in C4-fibre plants. With the exception of Herbaspirillum species 3, all species of

Published online ahead of print on 30 May 2003 as DOI 10.1099/ ijs.0.02677-0.

Abbreviation: TP-RAPD, two-primer randomly amplified polymorphic DNA.

The GenBank/EMBL/DDBJ accession number for the 16S rRNA gene sequence of Herbaspirillum lusitanum P6-12 ${ }^{\top}$ is AF543312.

Details of DNA $G+C$ contents, levels of DNA-DNA relatedness and pellicle formation by the novel isolates, transmission electron micrographs of cells, a 16S rDNA-based phylogenetic tree and RFLP and TP-RAPD patterns of the novel isolates are available as supplementary material in IJSEM Online.
Herbaspirillum are nitrogen-fixing bacteria able to establish close associations with plants (Reinhold-Hurek \& Hurek, 1998), even as endophytes in apoplastic (Elbeltagy et al., 2001; Olivares et al., 1997) or intracellular (James et al., 1997; Olivares et al., 1997) locations. When associated with plants, either as a causal agent of mild disease or as an asymptomatic bacterium, Herbaspirillum species have been found predominantly in species of the family Gramineae (Baldani et al., 1996; Kirchhof et al., 2001), and only exceptionally in other plants (Baldani et al., 1996).

Although it has been suggested for several years that the species of Herbaspirillum form a type of endophytic association in gramineous plants, in which they liberate fixed nitrogen and supply it to the plant (Döbereiner et al., 1993), direct experimental evidence for this observation has been recently obtained in rice (Oryza officinalis) inoculated with Herbaspirillum sp. strain B501 by using acetylene reduction and ${ }^{15} \mathrm{~N}_{2}$ gas incorporation assays (Elbeltagy et al., 2001).

Olivares et al. (1996) described the isolation of $H$. seropedicae not only from gramineae but also from roots of a legume species (Cajanus cajan); however, as these authors pointed 
out, the exact origin of this isolate is uncertain because small pieces of maize root may have been included in the sample. In the course of isolating bacteria from nodules of Phaseolus vulgaris plants growing in a soil from Portugal, we have isolated several bacteria that, based on their genotypic and phenotypic characterization, should be classified as a novel species of the genus Herbaspirillum, for which we propose the name Herbaspirillum lusitanum sp. nov. To our knowledge, this is the first report of the undoubted association of a bacterium of the genus Herbaspirillum with a leguminous plant.

The reference strains and novel isolates used in this study are listed in Table 1. A total of six novel herbaspirillum isolates was obtained from young nodules of five Phaseolus vulgaris plants growing in a soil from Sierra da Peneda in the northeast of Portugal. Isolations were made according to Vincent (1970) using YMA (Bergersen, 1961). The cultures used in further studies were purified from single colonies after 10 days of incubation at $28^{\circ} \mathrm{C}$. On YMA, colonies were mucoid, circular convex, white, slightly translucent and usually 1$2 \mathrm{~mm}$ in diameter within 2 days at $28^{\circ} \mathrm{C}$.

Gram-staining was performed as described by Doetsch (1981). Cell morphology was observed by scanning electron microscopy under a Zeiss EM900 electron microscope, with cells grown for 3 days at $28^{\circ} \mathrm{C}$ in liquid YED medium. Cells were Gram-negative and showed a short, curved rod morphology $(1.6 \times 0.5 \mu \mathrm{m})$. Cells were also grown in nutrient agar for $48 \mathrm{~h}$ to check for motility by phase-contrast microscopy. To observe flagella, cells were treated with $2 \%$ uranyl acetate and were observed under a Zeiss EM209 transmission electron microscope. Cells were motile and showed one or two polar flagella (see Supplementary Fig. A in IJSEM Online).

The 16S rRNA gene of a representative strain, P6- $12^{\mathrm{T}}$, was sequenced as described by Rivas et al. (2002). The sequence obtained was compared with those from GenBank using the FASTA program (Pearson \& Lipman, 1988). Sequences were aligned using CLUSTAL X software (Thompson et al., 1997) and distances were calculated according to Kimura's two-parameter method (Kimura, 1980). Phylogenetic trees were inferred using the neighbour-joining method (Saitou \& Nei, 1987). Bootstrap analysis was based on 1000 resamplings. The MEGA 2.1 package (Kumar et al., 2001) was used for all analyses. The trees were rooted using Comamonas testosteroni ATCC $11996^{\mathrm{T}}$ as the outgroup (Supplementary Fig. B). Sequence similarity calculations after neighbour-joining analysis indicated that the organism was phylogenetically related to members of the family 'Oxalobacteraceae'. The $16 \mathrm{~S}$ rDNA sequence of strain $\mathrm{P} 6-12^{\mathrm{T}}$ showed $97.9 \%$ similarity to that of $H$. frisingense, its closest relative, indicating that strain $\mathrm{P} 6-12^{\mathrm{T}}$ could constitute a novel species of the genus Herbaspirillum.

Determinations of DNA base composition and DNA-DNA hybridization analysis (Supplementary Table A) were performed as described by Arahal et al. (2001). The G+C contents of the six strains isolated in this study ranged from 57.9 to $61.9 \mathrm{~mol} \%$. These values are similar to those obtained for Herbaspirillum species. The results of DNADNA hybridization showed $92-98 \%$ relatedness between strain $\mathrm{P} 6-12^{\mathrm{T}}$ and the other five strains isolated. The relatedness of strain $\mathrm{P} 6-12^{\mathrm{T}}$ to $H$. frisingense DSM $13128^{\mathrm{T}}$, $H$. seropedicae DSM $6445^{\mathrm{T}}$ and $H$. rubrisubalbicans DSM $9440^{\mathrm{T}}$ was respectively 28,10 and $29 \%$. These results indicate that the strains isolated in this study do not belong to any of the known species of Herbaspirillum when the recommendation of a threshold value of $70 \%$ DNA-DNA relatedness for definition of species is considered (Wayne et al., 1987).

PCR products of $16 \mathrm{~S}$ rDNA amplification were digested with the restriction endonucleases DdeI and CfoI (AmershamPharmacia Biotech) as recommended by the manufacturer and electrophoresed in $2 \%$ agarose gels. Each endonuclease produced the same RFLP pattern in all strains isolated in this study, which was different from those obtained for Herbaspirillum species already described (Supplementary Fig. C).

TP-RAPD (two-primer randomly amplified polymorphic DNA) patterns were obtained according to Rivas et al.

Table 1. Strains used in this study

\begin{tabular}{|llc|}
\hline Strain & \multicolumn{1}{c|}{ Source } & Geographical origin \\
\hline P6-12 & Phaseolus vulgaris nodules & Portugal \\
P6-13 & Phaseolus vulgaris nodules & Portugal \\
P6-14 & Phaseolus vulgaris nodules & Portugal \\
P6-15 & Phaseolus vulgaris nodules & Portugal \\
P6-16 & Phaseolus vulgaris nodules & Portugal \\
P6-17 & Phaseolus vulgaris nodules & Portugal \\
H. seropedicae DSM $6445^{\mathrm{T}}$ & Oryza sativa roots & Brazil \\
H. seropedicae DSM 6447 & Zea mays roots & Brazil \\
H. frisingense DSM $13128^{\mathrm{T}}$ & Miscanthus sacchariflorus washed stems & Germany \\
H. rubrisubalbicans DSM $9440^{\mathrm{T}}$ & Saccharum officinarum roots & USA \\
\hline
\end{tabular}


(2001) by using the primer $849 \mathrm{~F}$ ( $5^{\prime}$-GCCTGGGGAGTACGGCCGCA-3'; Escherichia coli positions 829-849) and the reverse primer 1522R ( $5^{\prime}$-AAGGAGGTGATCCANCCRCA-3'; E. coli positions 1502-1522), both originally designed for amplification of $16 \mathrm{~S}$ rDNA. Each species of the genus Herbaspirillum showed a different pattern and all strains from this study showed the same pattern that was different from those of the species of the genus Herbaspirillum (Supplementary Fig. D). According to our previous results, strains showing different TP-RAPD patterns belong to different species (Rivas et al., 2001, 2002). Therefore, the TP-RAPD and RFLP patterns confirm the results obtained by $16 \mathrm{~S}$ rDNA sequence analyses, DNA base composition and DNA-DNA hybridization analyses and indicate that the novel isolates belong to a novel species of the genus Herbaspirillum.

The six strains isolated in this study, together with the type strain of the previously described species of Herbaspirillum, were subjected to several phenotypic tests. The ability to grow at temperatures between 20 and $40{ }^{\circ} \mathrm{C}$ and at $\mathrm{pH}$ values between 5 and 8 was determined on YMA medium. Catalase production was assayed by using $0.3 \%$ hydrogen peroxide with one colony taken from YMA plates. Oxidase activity was detected by using $N, N, N^{\prime}, N^{\prime}$-tetramethyl-1,4phenylenediamine dihydrochloride. For testing antibiotic resistance, API ATB G- strips (bioMérieux) were used following the manufacturer's instructions. Other physiological and biochemical tests were carried out using API 20NE and API ZYM strips (bioMérieux) following the manufacturer's instructions.

The six strains isolated in this work showed the same physiological and biochemical characteristics. Their range of temperature for growth was $20-35^{\circ} \mathrm{C}$. However, the known species of Herbaspirillum were able to grow at up to $40{ }^{\circ} \mathrm{C}$, which is in agreement with previous reports (Baldani et al., 1996; Kirchhof et al., 2001). All isolates were able to grow at $\mathrm{pH} 5-8$. The strains isolated in this study can be distinguished from previously described Herbaspirillum species on the basis of phenotypic properties such as nitrate reduction, $\beta$-galactosidase production, assimilation of $\mathrm{N}$-acetyl D-glucosamine, meso-inositol, meso-erythritol, L-rhamnose and arabinose and resistance to gentamicin, cefotaxime, ceftazidime, tobramicin, netilmicin and amikacin (Table 2).

Microaerophilic, dinitrogen-fixation-dependent growth was assessed by monitoring pellicle-forming ability on a nitrogen-free, semi-solid medium (Döbereiner, 1995), as described for $H$. frisingense (Kirchhof et al., 2001). All strains isolated in this study were able to grow, forming a pellicle, in such medium supplemented with malate, D-glucose, $\mathrm{N}$ acetyl D-glucosamine, L-arabinose, mannitol, D-fructose, Ltartrate and L-rhamnose, but not when supplemented with meso-inositol or meso-erythritol (Supplementary Table B). Furthermore, the presence of the nifD gene was confirmed by using a PCR approach with universal nifD primers (Stoltzfus et al., 1997). After electrophoresis in a $1.5 \%$
Table 2. Phenotypic characteristics of the type strains of Herbaspirillum species

Strains: 1 , H. seropedicae DSM $6445^{\mathrm{T}} ; 2$, H. rubrisubalbicans DSM $9440^{\mathrm{T}} ; 3, \mathrm{H}$. frisingense DSM $13128^{\mathrm{T}} ; 4, \mathrm{P} 6-12^{\mathrm{T}}$. All strains were positive for assimilation of glucose $e^{\star}$, mannose ${ }^{\star}$, mannitol ${ }^{\star}$, gluconate $^{\star}$, caprate ${ }^{\star}$, malate $^{\star}$, citrate ${ }^{\star}$ and phenylacetate ${ }^{\star}$ and production of alkaline phosphatase $\dagger$, esterase (C4)†, esterase lipase (C8) †, leucine arylamidase $\dagger$, valine arylamidase $\dagger$, cystine arylamidase $\dagger$, acid phosphatase $\dagger$ naphthol-AS-BI-phosphohydrolase $\dagger$ and urease*. All strains were negative for assimilation of maltose ${ }^{\star}$ and adipate $^{*}$, production of lipase $(\mathrm{C} 14) \dagger$, trypsin $\dagger$, chymotrypsin $\dagger$, $\alpha$-galactosidase $\dagger, \beta$-glucuronidase $\dagger, \alpha$-glucosidase $\dagger, \beta$-glucosidase $\dagger$, $N$-acetyl- $\beta$-glucosaminidase $\dagger, \alpha$-mannosidase $\dagger, \alpha$-fucosidase $\dagger$, arginine dihydrolase ${ }^{\star}$ and protease $^{*}$, indole production ${ }^{*}$ and glucose acidification ${ }^{*}$

\begin{tabular}{|c|c|c|c|c|}
\hline Test & 1 & 2 & 3 & 4 \\
\hline Reduction of nitrates to nitrites ${ }^{\star}$ & + & + & + & - \\
\hline$\beta$-Galactosidase ${ }^{\star} \dagger$ & + & + & + & - \\
\hline \multicolumn{5}{|l|}{ Assimilation of: } \\
\hline$N$-Acetyl D-glucosamine ${ }^{\star}$ & + & - & + & + \\
\hline meso-Inositol $\ddagger$ & + & - & - & - \\
\hline L-Rhamnose $\ddagger$ & + & - & - & + \\
\hline meso-Erythritol $\ddagger$ & - & + & - & - \\
\hline Arabinose $^{*}$ & + & + & - & + \\
\hline \multicolumn{5}{|l|}{ Resistance to $\left(\mu \mathrm{g} \mathrm{ml}^{-1}\right)$ : } \\
\hline Gentamicin (8) & + & - & - & - \\
\hline Cefotaxime (32) & - & + & + & + \\
\hline Ceftazidime (32) & + & - & - & + \\
\hline Tobramicin $(8)$ & + & + & - & - \\
\hline Netilmicin (8) & + & - & - & - \\
\hline Amikacin (16) & + & - & - & - \\
\hline
\end{tabular}

*Included in API 20NE strip.

$\dagger$ Included in API ZYM strip.

$\ddagger$ The mannitol component in YMA medium was replaced by the corresponding substrate.

agarose gel, a band of 390 bp was observed (data not shown), coinciding with the results obtained in $H$. frisingense (Kirchhof et al., 2001) and in other endophytic bacteria (Stoltzfus et al., 1997).

The infectivity of strain $\mathrm{P} 6-12^{\mathrm{T}}$ was assayed in Phaseolus vulgaris plants. Seeds of Phaseolus vulgaris were surfacesterilized for $10 \mathrm{~min}$ using $5 \%$ sodium hypochlorite and then washed repeatedly with sterile, distilled water. After sterilization, the seeds were sown in pots containing autoclaved vermiculite. One week after germination, roots were inoculated with $1 \mathrm{ml}\left(10^{5}\right.$ cells $)$ of a $48 \mathrm{~h}$ culture in YMB medium or with sterile water as a negative control. Two weeks after inoculation, plants were withdrawn from the pots and bacteria were reisolated from the roots as described by Elbeltagy et al. (2001). Finally, decimal dilutions were inoculated on YMA plates and incubated for $48 \mathrm{~h}$ at $28^{\circ} \mathrm{C}$. From these plates, several colonies were chosen at 
random and the identity of these isolates was checked by TP-RAPD fingerprinting (Rivas et al., 2001). Strain P6-12 was recovered from root tissues at concentrations of 2.3$3 \cdot 7 \times 10^{3}$ c.f.u. (g fresh weight) ${ }^{-1}$, which is in accordance with results reported for the species of Herbaspirillum known to be endophytes (Elbeltagy et al., 2000).

Therefore, on the basis of phylogenetic, genotypic and phenotypic data, we propose that the isolates from this study should be classified as the novel species Herbaspirillum lusitanum sp. nov.

\section{Description of Herbaspirillum lusitanum sp. nov.}

Herbaspirillum lusitanum (lu.si.ta'num. L. neut. adj. lusitanum of Lusitania, the Roman name of Portugal, where the strains reported in this study were isolated).

Gram-negative, aerobic, non-spore-forming curved cells, $1.6 \mu \mathrm{m}$ long and $0.5 \mu \mathrm{m}$ in diameter. Motile by polar flagella. Colonies on YMA are circular convex, white, slightly translucent and usually $1-2 \mathrm{~mm}$ in diameter within 2 days at $28{ }^{\circ} \mathrm{C}$. Carbon source utilization, hydrolytic enzyme production and resistance to antibiotics (including differentiating characters for all Herbaspirillum species) are indicated in Table 2. The $\mathrm{G}+\mathrm{C}$ content of the DNA is $59 \cdot 9 \pm 2 \mathrm{~mol} \%$.

The type strain is P6- $12^{\mathrm{T}}\left(=\mathrm{LMG} 21710^{\mathrm{T}}=\right.$ CECT $\left.5661^{\mathrm{T}}\right)$, isolated from root nodules of Phaseolus vulgaris plants grown in a soil from Sierra da Peneda (Portugal). Its DNA $\mathrm{G}+\mathrm{C}$ content is $57 \cdot 9 \mathrm{~mol} \%$.

\section{Acknowledgements}

This work was initiated as a collaboration with Drs Fernanda Mesquita and Manuel Judice Halpern (Instituto Superior da Ciencias da Saude, Lisbon) in the framework of a INTERREG II project. We are grateful to Dr J. González, M. Ortíz-Aranda and R. Martínez-Buey for help with electron microscopy preparations and to M. Sánchez for $16 \mathrm{~S}$ rDNA sequencing.

\section{References}

Arahal, D. R., García, M. T., Ludwig, W., Schleifer, K. H. \& Ventosa, A. (2001). Transfer of Halomonas canadensis and Halomonas israelensis to the genus Chromohalobacter as Chromohalobacter canadensis comb. nov. and Chromohalobacter israelensis comb. nov. Int J Syst Evol Microbiol 51, 1443-1448.

Baldani, J. I., Baldani, V. L. D., Seldin, L. \& Döbereiner, J. (1986). Characterization of Herbaspirillum seropedicae gen. nov., sp. nov., a root-associated nitrogen-fixing bacterium. Int J Syst Bacteriol 36, 86-93.

Baldani, J. I., Pot, B., Kirchhof, G. \& 8 other authors (1996). Emended description of Herbaspirillum; inclusion of [Pseudomonas] rubrisubalbicans, a milk plant pathogen, as Herbaspirillum rubrisubalbicans comb. nov.; and classification of a group of clinical isolates (EF group 1) as Herbaspirillum species 3. Int J Syst Bacteriol 46, $802-810$.
Bergersen, F. J. (1961). The growth of Rhizobium in synthetic media. Aust J Biol 14, 349-360.

Döbereiner, J. (1995). Isolation and identification of aerobic nitrogen-fixing bacteria from soil and plants. In Methods in Applied Soil Microbiology and Biochemistry, pp. 134-141. Edited by K. Alef \& P. Nannipieri. London: Academic Press.

Döbereiner, J., Reis, V. M., Paula, M. A. \& Olivares, F. L. (1993). Endophytic diazotrophs in sugar cane, tuber plants and cereals. In New Horizons in Nitrogen Fixation, pp. 671-676. Edited by R. Palacios, J. Mora \& W. E. Newton. Dordrecht: Kluwer.

Doetsch, R. N. (1981). Determinative methods of light microscopy. In Manual of Methods for General Bacteriology, pp. 21-33. Edited by P. Gerhardt, R. G. E. Murray, R. N. Costilow, E. W. Nester, W. A. Wood, N. R. Krieg \& G. B. Phillips. Washington, DC: American Society for Microbiology.

Elbeltagy, A., Nishioka, K., Suzuki, H., Sato, T., Sato, Y.-I., Morisaki, H., Mitsui, H. \& Minamisawa, K. (2000). Isolation and characterization of endophytic bacteria from wild and traditionally cultivated rice varieties. Soil Sci Plant Nutr 46, 617-629.

Elbeltagy, A., Nishioka, K., Sato, T., Suzuki, H., Ye, B., Hamada, T., Isawa, T., Mitsui, H. \& Minamisawa, K. (2001). Endophytic colonization and in planta nitrogen fixation by a Herbaspirillum sp. isolated from wild rice species. Appl Environ Microbiol 67, 5285-5293.

Gillis, M., Döbereiner, J., Pot, B., Goor, M., Falsen, E., Hoste, B., Reinhold, B. \& Kersters, K. (1990). Taxonomic relationships between [Pseudomonas] rubrisubalbicans, some clinical isolates (EF group 1), Herbaspirillum seropedicae and [Aquaspirillum] autotrophicum. In Nitrogen Fixation Associated with Non-legumes, pp. 293-294. Edited by M. Polsinelli, R. Materassi \& M. Vincenzini. Dordrecht: Kluwer.

James, E. K., Olivares, F. L., Baldani, J. I. \& Döbereiner, J. (1997). Herbaspirillum, an endophytic diazotroph colonizing vascular tissue in leaves of Sorghum bicolor L. Moench. J Exp Bot 48, 785-797.

Kimura, M. (1980). A simple method for estimating evolutionary rates of base substitutions through comparative studies of nucleotide sequences. J Mol Evol 16, 111-120.

Kirchhof, G., Eckert, B., Stoffels, M., Baldani, J. I., Reis, V. M. \& Hartmann, A. (2001). Herbaspirillum frisingense sp. nov., a new nitrogen-fixing bacterial species that occurs in C4-fibre plants. Int J Syst Evol Microbiol 51, 157-168.

Kumar, S., Tamura, K., Jakobsen, I. B. \& Nei, M. (2001). Molecular Evolutionary Genetics Analysis Software. Tempe, AZ: Arizona State University.

Olivares, F. L., Baldani, V. L. D., Reis, V. M., Baldani, J. I. \& Döbereiner, J. (1996). Occurrence of the endophytic diazotrophs Herbaspirillum spp. in roots, stems, and leaves, predominantly of Gramineae. Biol Fertil Soils 21, 197-200.

Olivares, F. L., James, E. K., Baldani, J. I. \& Döbereiner, J. (1997). Infection of mottled stripe disease-susceptible and resistant sugar cane varieties by the endophytic diazotroph Herbaspirillum. New Phytol 135, 723-737.

Pearson, W. R. \& Lipman, D. J. (1988). Improved tools for biological sequence comparison. Proc Natl Acad Sci U S A 85, 2444-2448.

Reinhold-Hurek, B. \& Hurek, T. (1998). Life in grasses: diazotrophic endophytes. Trends Microbiol 6, 139-144.

Rivas, R., Velázquez, E., Valverde, A., Mateos, P. F. \& MartínezMolina, E. (2001). A two primers random amplified polymorphic DNA procedure to obtain polymerase chain reaction fingerprints of bacterial species. Electrophoresis 22, 1086-1089.

Rivas, R., Velázquez, E., Willems, A., Vizcaíno, N., Subba-Rao, N. S., Mateos, P. F., Gillis, M., Dazzo, F. B. \& Martínez-Molina, E. (2002). 
A new species of Devosia that forms a unique nitrogen-fixing rootnodule symbiosis with the aquatic legume Neptunia natans (L. f.) Druce. Appl Environ Microbiol 68, 5217-5222.

Saitou, N. \& Nei, M. (1987). The neighbor-joining method: a new method for reconstructing phylogenetic trees. Mol Biol Evol 4, 406-425.

Stoltzfus, J. R., So, R., Malarvithi, P. P., Ladha, J. K. \& de Bruijn, F. J. (1997). Isolation of endophytic bacteria from rice and assessment of their potential for supplying rice with biologically fixed nitrogen. Plant Soil 194, 25-36.
Thompson, J. D., Gibson, T. J., Plewniak, F., Jeanmougin, F. \& Higgins, D. G. (1997). The CLUSTAL_X windows interface: flexible strategies for multiple sequence alignment aided by quality analysis tools. Nucleic Acids Res 25, 4876-4882.

Vincent, J. M. (1970). The cultivation, isolation and maintenance of rhizobia. In A Manual for the Practical Study of Root-Nodule Bacteria, pp. 1-13. Edited by J. M. Vincent. Oxford: Blackwell Scientific.

Wayne, L. G., Brenner, D. J., Colwell, R. R. \& 9 other authors (1987). Report of the ad hoc committee on reconciliation of approaches to bacterial systematics. Int J Syst Bacteriol 37, 463-464. 